\title{
CAPACITY BUILDING FOR CLIMATE CHANGE ADAPTATION: MODULES FOR AGRICULTURAL EXTENSION CURRICULUM DEVELOPMENT
}

\author{
B.O. Ogunbameru, S.B. Mustapha, Y.L. Idrisa, Researchers \\ Department of Agricultural Extension Services, University of Maiduguri, Nigeria \\ E-mail: shettimabulamamstp@gmail.com, Phone: +234(0)7060573884
}

\begin{abstract}
Basically, climate change refers to any change in climate overtime, generally caused by natural variability and/or human activities. It has great devastating impact, particularly on agriculture and by extrapolation on farmers and the national economy. The frontline agricultural extension workers are expected to be among the principal stakeholders to teach farmers how to cope with climate change. Consequently, there is a need to develop appropriate teaching package for the training of the frontline agricultural extension workers, based on the myriad of adaptation strategies and practices available in the literature. This paper synthesizes the rationale for capacity building in climate change and the adaptation or coping strategies. The modules (train-the-trainer) for teaching agricultural extension workers and farmers are documented in the paper.
\end{abstract}

\section{KEY WORDS}

Climatic change; Adaptability; Adaptation; Climate; Land use; Precipitation; Buildings.

Climate is defined as long-term weather patterns that describe a specific region or place Elements of the weather patterns include temperature, cloudiness, humidity, precipitation, and winds (CCIR, 2005). Global climate change indicates a change in either the mean state of the climate or in its variability, persisting for several decades.

The changes in climate are attributed directly to: human activities; and the composition of the global atmosphere over comparable time periods (IPCC, 2007; Ozor, 2009). Increase in green house gases (GHGs) emission through human activities has resulted in additional warming of the earth's surfaces, with several anticipated disastrous impacts (Harris, 1999; Mortimore, M.J.; Harnis, F.M.A. and Adams, W.M. 2000).

Climate is the primary determinant of agricultural production and productivity (Apata, $T$. G., Samuel, K. D. and Adeola, A. 0.2009; Smith and Skinner, 2002). Adverse climate effects can influence farming outputs - crop, livestock and fish production and invariably on human livelihood. The focus on climate change issue largely centres nowadays on enhancing the capacity of developing nations (Nigeria inclusive) to adapt to the climate change impacts (Jones, 2010).

Agricultural extension is defined as a series of embedded communicative interventions which supposedly help to resolve problematic situations (Leeuwis, 2006; Ogunbameru, 2001). This definition confers on agricultural extension the responsibility to accommodate the issue of climate change in its duties (Ozor, 2009).

Four key roles have been proposed for extension in agricultural adaptation to climate change, namely;

- training and re-training of extension staff to acquire new capacity in climate change management;

- setting up of emergency management units in extension agencies;

- dissemination of innovations on best adaptation practice; and

- improving feedback to government and interested agencies on climate change issues (Ozor and Nnaji, 2011).

Consequently, there is a need to enhance the capacity of professional frontline extension workers on climate change issues such as causes of climate change, its effects and adaptation strategies (Ozor, 2009). Essentially, their knowledge base on climate change should be expanded.

Problem Statement. The capacity of professional/frontline extension workers need to be enhanced so that they in turn will be able to train farmers. Whereas, a number of 
adaptation strategies have been identified, proven and documented in literature, unfortunately, no attempt has been made to develop appropriate training curriculum that captures, in modular form, the various adaptation strategies. This paper therefore attempts to design a curriculum for Diploma and undergraduate training programmes for agricultural tertiary institutions in Nigeria. The modules can also be used in training the extension staff currently on the field.

Objectives of the Study. The specific objectives of the study were to:

- highlight the relevant information on climate change, including its causes and impacts;

- inventorise the various climate change adaptation strategies; and

- develop the modules on climate (based on the above objectives I and II) for the training of both professional/frontline extension workers on ground and potential extensionists during their training.

\section{RESEARCH METHODOLOGY}

Existing current documents/literature on climate change were assembled and critically reviewed, considering their currency. The gathered information were tabulated in modular forms and presented herein.

Presentation: A total of four (4) modules were developed that could be used for trainthe-trainer capacity building on climate change.

Module I: Definition of climate change, mitigation and adaptation;

Module II: Causes of climate change;

Module III: Impacts of climate change; and

Module IV: Adaptation strategies.

The modules are suggested to be part of General Studies for agricultural students in tertiary institutions, particularly in the colleges and faculties of agriculture in universities.

Module I: Definitions of Climate Change, Mitigation and Adaptation.

- Climate Change: Climate change refers to any change in climate overtime, either due to natural variability or as a result of human activity (IPCC, 2001). The changes occur due to variation in different climatic parameters as a result of human activities and natural phenomenon. Responding to climate change falls into two broad actions, namely: (a) mitigation and (b) adaptation.

- Mitigation: Mitigation to human - induced climate change refers to measures that may either reduce the increase in greenhouse emissions (abatement) or increase terrestrial storage of carbon (Oladipo, 2010).

- Adaptation: Adaptation refers to all the responses to climate change that may be used to reduce vulnerability. Vulnerability is susceptibility to harm, or damage potential. It encompasses such factors as the ability of a system to cope with or absorb stress or impacts and to "bounce back" or recover i.e. preparedness to respond to climate change through effective adaptation measures (Oladipo, 2010).

Adaptation means actions targeted at the vulnerable system in response to actual or expected climate stimuli with the objective of moderating harm from climate change or exploiting opportunities (McCarthy, J.J., Camziani, O.F. Leary, N.A., Dokken, D.J. and White, K.S. 2001). Adaptation is relevant for all climate sensitive domains, including agriculture, forestry, water management, coastal protection, public health, and disaster prevention (Fussel, 2007). Responding to climate change through adaptation initiatives requires a concerted effort to reduce the vulnerability of the people to climate change impacts (Oladipo, 2010).

Module II: Causes of Climate Change.

According to IPCC (2007), the changes in climate are attributed directly to human activities and the composition of the global atmosphere over comparable time period.

The changes occur due to variation in different climatic parameters, including:

- Cloud cover; 
- Precipitation;

- Temperature;

- Vapour pressure (ERM, 2009);

- Increase in green house gases (GHG) emission through human activities has resulted in additional warming of the earth's surface (Harris, 1999; Mortimore et al. 2000);

- The global increases in carbon (iv) oxide $\left(\mathrm{CO}_{2}\right)$ concentration are due primarily to fossil fuel use and land use change;

- Increased release of methane $\left(\mathrm{CH}_{4}\right)$ and nitrous oxide $\left(\mathrm{N}_{2} \mathrm{O}\right)$ to the atmosphere are caused primarily by agricultural activities (IPCC, 2007), including clearing of forests for farming.

Module III: Impacts of Climate Change.

Climate change has devastating impacts on human being, environment and agriculture. Climate change elicits a significant change in agricultural production both in terms of the quantum of products as well as the location or area of production (Oladipo, 2010). These have adverse implication for food security and livelihood of the people. Catalogues of the negative effects/impacts of climate change are summarized as follows:

Impact of Climate Change on Agriculture: Agriculture is most sensitive to global warming climate change. Agricultural production could decline between 10-25\% the decline in rain-fed agriculture could be as much as 50\% (Oladipo, 2010).

- Stunted growth of crops;

- Easy spread of pests and diseases attack on crops, livestock and fish;

- Drying of seedlings after germination and transplanting;

- Low yield of crops and/or crop failure;

- Low quality of farm produce;

- Fall in farm revenues/incomes (economic losses);

- Isolated location of farms;

- Small farm size;

- Low level of technology adoption;

- Reduced supply of raw materials for agro-based industries;

- Impact on water resources;

- Later fruiting of fruit trees.

Impact on water resources: Climate change leads to increased variability in rainfall, predictably resulting in floods in humid areas in southern Nigeria and decrease in precipitation resulting in drought in the north.

- Higher temperature changes affect the amount of runoff that becomes groundwater.

- Reduced river flow will reduce hydropower reservoir storage and thus reduce potential energy production.

- Drying-up of streams/rivers.

- Fast water evaporation from the ground.

Impact on Socio-Economic and Socio-Cultural Sectors: Highlights of the impacts of climate change on the socio-economic lives of people include:

- Population settlements;

- Health;

- Tourism;

- Transport;

- Economic poverty;

- Increased hunger/famine;

- Conflict;

- Informal land tenure;

- Sale of assets;

- Indebtedness;

- Out-migration/Relocation of Settlements or villages; 
- Dependency on food aids;

- Insecurity of lives/livelihood;

- Unemployment.

Impact on Environment: Climate change has direct impact on biodiversity-from ecosystem to species level, such as:

- Increased frequency and intensity of severe weather events. Sea level rise may lead to increasing inundation and flooding, particularly in low-lying areas;

- Increased existing risks of extinction of many threatened species or leads to loss of biodiversity;

- Increased pressure on ecology and ecosystem-loss of biodiversity, rapid deterioration in land cover and depletion of water availability;

- Water logging due to accelerated sea level rise;

- Increased difficulty in forest regeneration;

- Increased vulnerability to soil erosion (rainfall-induced erosion and wind erosion);

- Longer days than night.

Module IV: Adaptation Strategies. Adaptation strategies are those methods that enable individual or the community to cope with or adjust to the impacts of climate change (Jones, 2010; Nyong et al., 2007). Such strategies include the adaptation of: (1) early maturing crops; (2) drought resistant varieties; and (3) selective keeping of livestock in areas where rainfall declines. It is imperative that agriculture and agricultural practices must adapt to climate change.

Parry (1990) suggested two possible adjustment or coping strategies, namely; (1) changes in land use; and (2) changes in management.

Changes in land use are changes in a shift:

- towards the cultivation of crops with higher thermal requirements;

- to cultivation of more drought-tolerant crops with lower moisture.

Changes in management measures include:

- Use of irrigation;

- Use of fertilizer;

- Use of fallowing-movement to different site yearly;

- Use of intercropping, mixed farming and crop rotation;

- Use of hybrid seedlings;

- Increases in the area cultivated;

- Adjustment of sowing dates;

- Combining less productive drought-resistant cultivars and high yielding but water sensitive crops.

Ayanwuyi, E., Kuponiyi, E., Ogunlade, F.A. and Oyetoro, J.O.(2010) recommended five (5) pathways as adaptation strategies, including: (1) adaptation; (2) farming operatives; (3) protection measure (4) household livelihood; and (5) education and finance.

Adaptation Strategies to Climate Change (Source: Ayanwuyi et al., 2010).

1. Adaptation:

- Water conservation techniques (precision farming);

- Increase (intensification) or reduce (intensification) land size cultivated;

- Move to different site;

- Increase irrigation;

- Soil conservation;

- Shading and shelter/mulching.

2. Farming Operations:

- Planting of different crops;

- Planting of different varieties;

- Early planting;

- Early harvesting when dry soil is expected;

- Apply more or fewer inputs (fertilizers, agro-chemicals); 
- Different planting dates;

- Treat seeds with fungicides before sowing;

- Mixed farming;

- Zero tillage;

- Changes from crop production to livestock production.

3. Protection Measure:

- Chance row orientation with respect to slopes;

- Apply soil amendments e.g. farm yard manure;

- Increase fertilizer application three days prior to sowing.

4. Household Livelihood:

- Undertake non-farm economic activities;

- Avoid selling remaining food stocks;

- Reduce expenditure;

- Ration food;

- Migrate.

5. Education and Finance:

- Access to extension facilities;

- Access to credit facilities;

- Government policies.

\section{CONCLUSION}

It is well established that climate change poses a serious threat to agricultural production, particularly on rain-fed agriculture. For instance, climate change results in stunted growth and low yield of food crops, late fruiting of tree crops, easy spread of pests and diseases attacks on crops and livestock. Recommended adaptation or coping strategies to climate change include, inter alia; water conservation techniques (precision farming); planting of different crops/varieties, mixed farming and early planting.

There is a need to integrate or mainstream curriculum on climate change into the academic programmes of tertiary institutions offering agriculture particularly the federal and state college of agriculture and faculties of agriculture in the Nigerian universities.

The five modules should be used as general guidelines for capacity building or development. The professional extension workers must be well knowledgeable about climate change so as to be able to competently and effectively impart same knowledge to the farmers.

\section{REFERENCES}

[1] Apata, T.G., Samuel, K.D. and Adeola, A.O. (2009). Analysis of Climate Change Perception and Adaptation among Arable Food Crop Farmers in South Western Nigeria. A contributed paper prepared for presentation at the International Association of Agricultural Economists' Conference, Beijing, China, August 16-12, Pp 1-15.

[2] Ayanwuyi, E., Kuponiyi, E., Ogunlade, F.A. and Oyetoro, J.O. (2010). Farmers, Perception of Impact of Climate Changes on Crop Production in Ogbomosho Agricultural Zone of Oyo State, Nigeria. Global Journal of Human Social Science, vol. 10 , issue 7, pp. 33-39.

[3] CCIR-Climate Change Information Resources (2005) What Causes Global Climate Change. New York. Metropolitan Region.

[4] Environmental Resources Management (2009). Impact of Climate change on Nigeria'seconomy.http://pak-nigeria.org/pdfs/27-impact-of-climate-change-onnigerias-economy.pdf. Accessed January, 2011. 
[5] Fussel, H.M. (2007). Adaptation Planning for Climate Change: Concepts, Assessment Approaches, and Key Lessons. Integrated Research System for Sustainability Science and Springer (2): 265-275.

[6] Harris, F. (1999). Nutrient Management Strategies of Small-Holder Farmers in a Short Fallow Farming System in North-East Nigeria. Geographical Journal 165:275-285.

[7] IPPC-Inter governmental Panel on Climate Change. (2007). Climate Change-Impacts, Adaptation and Variability: Contribution of Working Group JP II to the fourth Assessment Report. Cambridge University Press, Cambridge UK.

[8] Jones, L. (2010), Overcoming Social Barriers to Adaptation. Overseas Development Institute (ODI) Background Note, www.odi.org.uk/50years.

[9] Leeuwis, C. (2006), Communication for Rural Innovation: Re-thinking Agricultural Extension, $3^{\text {rd }}$ edition. The Netherlands, Publishing, p. 27.

[10] McCarthy, J.J., Camziani, O.F. Leary, N.A., Dokken, D.J. and White, K.S. (2001). Climate Change: Impacts, Adaptation and Vulnerability. Cambridge University Press, Cambridge.

[11] Mortimore, M.J.; Harnis, F.M.A. and Adams, W.M. (2000). The Relevance of Nigerian Farmers Responses to Dry land Farming Systems in India and Southern Africa. Department for International Development Renewable Natural Resources Research Strategy, Semi-Arid Production System, Project R7093.

[12] Ogunbameru, B.O. (2001). Practical Agricultural Communication. Daily Graphics of Nigeria Limited, Ibadan.

[13] Oladipo, Emmanuel (2010)., Towards Enhancing the Adaptative Capacity Of Nigeria: A Review of the Country's State of Preparedness for Climate Change Adaptation. Henrich Boll Foundation, Nigeria.

[14] Ozor, N. (2009), Understanding Climate Change: Implications for Nigerian Agriculture, Policy and Extension. Paper Presented at the National Conference on "Climate Change and the Nigerian Environment', held at the University of Nigeria, Nsukka, June 29-July 2.

[15] Ozor, N. and Nnaji, C. (2011). The Role of Extension in Agricultural Adaptation to Climate Change in Enugu State, Nigeria. Journal of Agricultural Extension and Rural Development, vol. 3 (3), pp. 42-50.

[16] Smith, B. and Skinner M. (2002). Adaptation options in Agriculture to Climate Change: A Typology Mitigation and Adaptation Strategies for Global Change. African Journal of Agriculture and Resource Economics 3 (5), pp. 78-82. 